\title{
IMPROVED YIELD, FRUIT QUALITY, AND SHELF LIFE IN 'FLAME SEEDLESS' GRAPEVINE WITH PRE-HARVEST FOLIAR APPLICATIONS OF FORCHLORFENURON, GIBBERELLIC ACID, AND ABSCISIC ACID
}

\author{
Hoda A. KHALIL* \\ Department of Pomology, Faculty of Agriculture (El-Shatby), \\ Alexandria University, Alexandria, Egypt \\ Received: July 2019; Accepted: April 2020
}

\begin{abstract}
The effect of gibberellic acid ( $\mathrm{GA}_{3}$ ), forchlorfenuron (CPPU), and abscisic acid (ABA) on the parameters of yield of 'Flame Seedless' grapes was investigated. The clusters of 8-year-old grapevines were sprayed with solutions: $\mathrm{GA}_{3}$ at $25 \mathrm{mg} \cdot \mathrm{dm}^{-3}, \mathrm{CPPU}$ at $10 \mathrm{mg} \cdot \mathrm{dm}^{-3}$, and $\mathrm{ABA}$ at $300 \mathrm{mg} \cdot \mathrm{dm}^{-3}$, alone or in combinations. $\mathrm{GA}_{3}$ and CPPU treatment increased yield, cluster weight and length, berry weight and diameter, as well as fruit firmness, but reduced the total soluble solids (TSS) and intensity of berry color. Anthocyanin content of berries treated with $\mathrm{GA}_{3}$ and CPPU increased significantly by ABA treatment. Shelf life was increased by $\mathrm{GA}_{3}$ and CPPU treatments, as they decreased the percentage of weight loss, shattering, and unmarketable berries after storing at $20{ }^{\circ} \mathrm{C}$ for 7 days. Thus, it can be concluded that the combined use of $\mathrm{GA}_{3}, \mathrm{CPPU}$, and $\mathrm{ABA}$ may be an efficient practice for fruit enlargement, coloration, and keeping quality in 'Flame Seedless' grape.
\end{abstract}

Key words: forchlorfenuron, CPPU, berry size, fruit quality, anthocyanins, ABA

\section{INTRODUCTION}

Grapes (Vitis vinifera L.) are one of the most favorite and common fruits in the world for its desirable scent and high soluble solid content. Fruit quality is more influential than yield in the production of excellent table grapes (Peppi et al. 2006). Grape quality is remarkable for the producer, consumer, and the exporter. Important characteristics that participate in the quality of grapes include their size, texture, taste and color. These characters could be modified with the use of plant growth regulators (PGRs) if their use is permitted under national regulations as, for example, in the USA, Italy, Australia, and Chile (Ferrara et al. 2015). Previous studies presented that plant growth regulators play an important role in fruit production, such as increase in berry weight of grape (Casanova et al. 2009), enlargement of fruit size in grape (Xu et al. 2019), apple (Muchjajib et al. 2016) and mandarin (Duarte et al. 2006), improving fruit set in mango (El Gammal et al. 2015), reducing fruit drop in apple (Khandaker et al. 2015), enhancing yield and quality of pomegranate (Adi Reddy \& Manohar Prasad 2012), and delaying ripening of grapes (Ponce et al. 2002). Forchlorfenuron (CPPU), a synthetic cytokinin, and gibberellic acid $\left(\mathrm{GA}_{3}\right)$ are commonly applied by table grapes producers to improve berry size and firmness (Du Plessis 2008; Zoffoli et al. 2009; Xu et al. 2019). GA 3 stimulates cell expansion in the berries, while CPPU causes cells division (Ben-Arie et al. 1998). However, Korkutal et al. (2008) reported that GAs applied at too early time with extremely high concentration decreases vine vigor, which negatively impacts the fruit yield. 'Flame Seedless' has a particularly durable response to CPPU, in particular berry size (Melillo 2005); however, it reacts with reduced color intensity.

CPPU and $\mathrm{GA}_{3}$ increase berry size as a desirable effect, but they also inhibit color development, which restricts their use on colored grape cultivar. 
A dosage of $8 \mathrm{~g}$ per acre of CPPU, applied to 'Flame Seedless' at fruit set increased berry size but also reduced color and delayed maturity (Peppi \& Fidelibus 2008). Ethephon was applied to table grapes to enhance berry color, but its impacts are inconsistent and can lead to berry softening (Szyjewicz et al. 1984; Peppi et al. 2006). Abscisic acid (ABA) was found as an efficient alternative to ethephon for enhancing the color of table grapes (Koyama et al. 2019; Lurie et al. 2010). It is easier for application due to less restrictive period of its use, and an exemption from the requirement to have a tolerance in most countries (Ferrara et al. 2015), but the high cost has prevented the development of its practical applications for viticulture (Peppi et al. 2006). However, recently, the introduction of $\mathrm{ABA}$ as an active ingredient of a commercial plant growth regulator (ProTone ${ }^{\circledR}$ ) motivated many studies on Vitis vinifera cultivars grown under temperate climate conditions. When ABA is applied to grape, the ripening stage is accelerated by reducing the chlorophyll quantity and improving the color change (Gény et al. 2005). Many investigations have shown that the application of ABA may significantly stimulate the activity of several genes involved in and related to anthocyanin biosynthesis (He et al. 2010). The physiological activity of ABA sprays was proved by determining the mRNA levels of the key anthocyanin gene - flavonoid glucosyltransferase (UFGT) from the skin of 'Crimson Seedless' grapes treated with ABA applied at veraison (change of color) stage. The level of UFGT mRNA increased considerably within one day after application (Olivares et al. 2017). ABA can increase the anthocyanins' content and enhance the color of 'Flame Seedless' grapes, however, it likewise causes fruit softening, which is an undesirable effect (Peppi et al. 2006). The combined use of $\mathrm{GA}_{3}$, CPPU and ABA might be advantageous if the result will cause large, firm berries of sufficient color. Thus, the aim of this study was to assess if the application of CPPU and $\mathrm{GA}_{3}$ followed by ABA might increase the size and firmness of 'Flame Seedless' grapes without extremely inhibiting coloring. Moreover, the effects of $\mathrm{GA}_{3}, \mathrm{CPPU}$ and $\mathrm{ABA}$ on the yield, fruit quality at harvest day and on the berry shelf life of 'Flame Seedless' grape was investigated.

\section{MATERIALS AND METHODS}

\section{Plant materials and treatments}

This research was conducted in 2016 and 2017 seasons at a private farm in Marriott region, $40 \mathrm{~km}$ at Alexandria-Cairo desert road (lat. $30.93^{\circ} \mathrm{N}$, long. $29.78^{\circ} \mathrm{E}$ ), Egypt. Own-rooted eight year old grapevines (Vitis vinifera L. 'Flame Seedless') grown in a sandy soil under drip irrigation system were used in this experiment. The grapevines were grown in raised beds ( $0.3 \mathrm{~m}$ high and $1.5 \mathrm{~m}$ wide) and spaced $1.5 \mathrm{~m}$ between vines and $4.5 \mathrm{~m}$ between rows at a $2 \mathrm{~m}$ high horizontal shoot-positioned trellis system. Vines were pruned to 15 canes per each vine with 12 nodes per cane in winter pruning. A weekly fertigation with a complete liquid fertilizer was applied and a regular pest management program was maintained. The experiment was arranged in a randomized complete block design (RCBD). Each of the five treatments was replicated three times with two vines per replicate. The clusters of 'Flame Seedless' grape were sprayed with $25 \mathrm{mg} \cdot \mathrm{dm}^{-3} \mathrm{GA}_{3}$, $10 \mathrm{mg} \cdot \mathrm{dm}^{-3} \mathrm{CPPU}$ ((N-(2-chloro-4-pyridyl)-N'-phenylurea, and $300 \mathrm{mg} \cdot \mathrm{dm}^{-3} \mathrm{ABA}$ solutions, alone or in combination; $\mathrm{GA}_{3}$ and $\mathrm{CPPU}$ were applied at the $\mathrm{BBCH} 75$ phase (berries diameter 7-8 $\mathrm{mm}$ ) and ABA at $\mathrm{BBCH} 81$ phase (approximately when $10 \%$ of the berries began to soften). Treatments were applied to the clusters with a handheld sprayer until runoff. Triton B at $0.05 \%$ was used as a surfactant agent.

\section{Vine yield and initial harvest date}

In the two seasons, clusters were harvested when considered to have surpassed the minimum market necessities (commercially acceptable) of $16.5-18 \%$ total soluble solids (TSS), 22:1 total soluble solids: titratable acidity ratio and complete red berry coloring. All the harvested clusters were weighed $(\mathrm{g})$ and the total yield (kg per vine) was recorded. In addition, the initial harvest date for each treatment was also recorded.

\section{Physical and chemical characteristics}

At harvest, a sample of 3 clusters for each replicate was randomly picked in both seasons and their average weights and lengths were determined. All picked clusters per each replicate were fully destemmed and a 100 berry sample was used to determine berry weight utilizing a technical balance. 
An average of twenty berries from each sample were collected and used to determine berry diameter $(\mathrm{mm})$ by a caliper. On the same berries' sample, firmness was measured using a penetrometer (Effegi, 48011 Alfonsine, Italy) with $3 \mathrm{~mm}$ diameter plunger. The firmness of berries was expressed as $\mathrm{N}$.

Another sample of 3 clusters was randomly picked at harvest from each replicate. In the juice, total soluble solids (TSS) percent were measured as ${ }^{\circ}$ Brix by a hand refractometer (ATC-1E, Atago, Japan) and titratable acidity (TA) percent was determined by titration with $0.1 \mathrm{~N} \mathrm{NaOH}$ according to AOAC (1995). Berries' skin color characteristics (lightness $-L^{*}$, chroma $-C^{*}$, and hue angle $-h^{\circ}$ ) were determined on 3 points around the equator of each berry by a Minolta Color meter (CR-200, Japan) (Peppi et al. 2006). Lightness $\left(L^{*}\right)$ represents black to white from 0 to 100 , chroma $\left(C^{*}\right)$ represents the purity of color, and hue angle $\left(h^{\circ}\right)$ refers to the red, yellow, green, and blue colors. Ten berries per each cluster were randomly collected and separated from the pedicel and the berries' skins were manually separated from the fruit pulp. Anthocyanin was extracted from $0.1 \mathrm{~g}$ skin samples with $1.0 \% \mathrm{HCl}$-methanol overnight in the dark at room temperature, and the absorbance of each sample was measured at $525 \mathrm{~nm}$ by spectrophotometer. Readings were expressed as mg $100 \mathrm{~g}^{-1} \mathrm{FW}$ cyanidin-3monoglucoside equivalent (Peppi 2004).

\section{Shelf life}

To demonstrate the effectiveness of treatments in extending shelf-life and quality of grapes, a random sample of four clusters per each replicate were individually packaged in perforated plastic film bags and stored at $20^{\circ} \mathrm{C}(\mathrm{RH}=80-85 \%)$ for 7 days. Berry firmness was measured using a penetrometer as described above. Determinations were made with 10 berries for each replicate. Clusters were weighed before placing into the bags (initial weight) and their weights were recorded three times during the storage period and expressed as a percentage of water loss compared to initial weight. Berry shattering (separation from a cluster) was determined for each cluster by deducting the weights of detached berries from the total cluster weight (Cantín et al. 2007) and expressed as percentage. At the end of the storage period, clusters were examined and berries that had quality defects such as decay or shriveling were removed and then weighed to obtain the percent of commercially unmarketable berries.

\section{Statistical analysis}

Data of the experiments were tested for the effects of treatments on the analyzed parameters by using the one-way analysis of variance (ANOVA). Differences among treatments were separated and compared using the Duncan's test at probability level of 0.05 according to Snedecor and Cochran (1989). The statistical analysis was performed using SPSS software package (SPSS v. 18 PASW).

\section{RESULTS}

\section{Vine yield}

Results of both seasons (Table 1) showed a significant increase in grapevine yield by all sprayed treatments compared to the control. Combined treatment of $\mathrm{GA}_{3}+\mathrm{CPPU}$ resulted in significantly higher yield value than $\mathrm{GA}_{3}, \mathrm{CPPU}$, and $\mathrm{GA}_{3}+\mathrm{CPPU}+\mathrm{ABA}$, which did not significantly differ among each other.

\section{Cluster and berry physical characteristics at harvest} In both seasons, a significant increase in the weights and length of the clusters was recorded in all treatments where plant growth regulators were applied as compared to the control (Table 1). The $\mathrm{GA}_{3}+$ CPPU treatment resulted in a significantly higher cluster weight than $\mathrm{GA}_{3}, \mathrm{CPPU}$, and $\mathrm{GA}_{3}+$ $\mathrm{CPPU}+\mathrm{ABA}$ treatments. The longest clusters were recorded due to spraying $\mathrm{GA}_{3}$ and $\mathrm{GA}_{3}+\mathrm{CPPU}$ in the second season. In the meanwhile, $\mathrm{GA}_{3}, \mathrm{CPPU}$, and $\mathrm{GA}_{3}+\mathrm{CPPU}+\mathrm{ABA}$ treatments did not differ among each other in their influence on cluster length in the first season. Moreover, weight of 100 berries also increased in all treatments where growth regulators were applied in both seasons. Spraying with $\mathrm{CPPU}, \mathrm{GA}_{3}+\mathrm{CPPU}$, and $\mathrm{GA}_{3}+\mathrm{CPPU}+\mathrm{ABA}$ in the first season, increased berry weight when compared with the control and $\mathrm{GA}_{3}$ treatments, with no significant difference among them were obtained. While, in the second season, $\mathrm{GA}_{3}+\mathrm{CPPU}$ treatment caused significantly higher berries' weights than was obtained in all other treatments with the growth regulators. Furthermore, spraying $\mathrm{GA}_{3}+\mathrm{CPPU}+\mathrm{ABA}$ had higher berry diameter values than spraying $\mathrm{GA}_{3}, \mathrm{CPPU}, \mathrm{GA}_{3}+\mathrm{CPPU}$ and control in both seasons 
The results of both seasons showed that the firmer berries were recorded due to spraying with $\mathrm{GA}_{3}$ or CPPU and both of them compared to the control and $\mathrm{GA}_{3}+\mathrm{CPPU}+\mathrm{ABA}$ treatment (Table 2). In the first season, CPPU caused higher berry firmness value followed by $\mathrm{GA}_{3}+\mathrm{CPPU}$ and $\mathrm{GA}_{3}$. Whereas, in the second season, there were no significant differences among them for berry firmness.

\section{Initial harvest date}

Data in Table 2 show that $\mathrm{GA}_{3}, \mathrm{CPPU}$ and $\mathrm{GA}_{3}+$ CPPU delayed the initial harvest date in comparison with the control treatment, with the latest harvest date recorded in $\mathrm{GA}_{3}+\mathrm{CPPU}$ treatment followed by CPPU then $\mathrm{GA}_{3}$. On the contrary, in both seasons, an earlier harvest date was recorded by spraying $\mathrm{GA}_{3}+\mathrm{CPPU}+\mathrm{ABA}$ as compared to the control.

\section{Chemical characteristics}

The effect of different treatments on the chemical characteristics of the berries at harvest is shown in Tables 2 and 3. A significant decrease in total soluble solids (TSS) content was obtained in both seasons, by using $\mathrm{GA}_{3}, \mathrm{CPPU}$, and $\mathrm{GA}_{3}+\mathrm{CPPU}$ compared to the control and $\mathrm{GA}_{3}+\mathrm{CPPU}+\mathrm{ABA}$ treatments, which did not significantly differ between each other. Berry acidity content (TA) was not affected by any of the sprayed growth regulators in the second season while in the first $\mathrm{GA}_{3}+\mathrm{CPPU}$, increased acidity (TA) as compared with the remaining treatments.

Table 1. Effect of the growth regulators on yield, cluster weight, cluster length, the weight of 100 berries, and berry diameter of 'Flame Seedless' grape at harvest during 2016 and 2017 seasons

\begin{tabular}{|c|c|c|c|c|c|c|c|c|c|c|}
\hline & \multicolumn{2}{|c|}{$\begin{array}{l}\text { Yield per vine } \\
(\mathrm{kg})\end{array}$} & \multicolumn{2}{|c|}{$\begin{array}{l}\text { Cluster weight } \\
(\mathrm{g})\end{array}$} & \multicolumn{2}{|c|}{$\begin{array}{l}\text { Cluster length } \\
(\mathrm{cm})\end{array}$} & \multicolumn{2}{|c|}{$\begin{array}{l}\text { Weight of } 100 \text { berries } \\
(\mathrm{g})\end{array}$} & \multicolumn{2}{|c|}{$\begin{array}{l}\text { Berry diameter } \\
(\mathrm{cm})\end{array}$} \\
\hline & 2016 & 2017 & 2016 & 2017 & 2016 & 2017 & 2016 & 2017 & 2016 & 2017 \\
\hline Control & $9.2 \pm 0.5 \mathrm{c}$ & $10.5 \pm 0.5 \mathrm{c}$ & $183.0 \pm 1.4 \mathrm{~d}$ & $203 \pm 4.1 \mathrm{e}$ & $11.0 \pm 0.8 \mathrm{~b}$ & $12.0 \pm 0.2 \mathrm{c}$ & $160 \pm 2.8 \mathrm{c}$ & $170 \pm 5.7 \mathrm{~d}$ & $11.2 \pm 0.1 \mathrm{~d}$ & $11.2 \pm 0.1 \mathrm{c}$ \\
\hline $\mathrm{GA}_{3}$ & $12.1 \pm 1.1 \mathrm{~b}$ & $13.0 \pm 0.6 \mathrm{bc}$ & $221.0 \pm 4.3 \mathrm{c}$ & $289.3 \pm 6.2 \mathrm{~d}$ & $18.2 \pm 0.1 \mathrm{a}$ & $19.7 \pm 0.1 \mathrm{a}$ & $210 \pm 5.7 \mathrm{~b}$ & $225 \pm 2.8 \mathrm{c}$ & $12.4 \pm 0.1 \mathrm{c}$ & $12.8 \pm 0.1 \mathrm{bc}$ \\
\hline CPPU & $13.3 \pm 1.1 \mathrm{ab}$ & $13.2 \pm 0.7 \mathrm{ab}$ & $350.3 \pm 14.4 \mathrm{~b}$ & $350.2 \pm 2.8 \mathrm{~b}$ & $17.2 \pm 1.2 \mathrm{a}$ & $18.2 \pm 0.4 \mathrm{~b}$ & $287 \pm 4.0 \mathrm{a}$ & $300 \pm 2.8 \mathrm{~b}$ & $13.7 \pm 0.3 \mathrm{~b}$ & $12.7 \pm 0.3 \mathrm{bc}$ \\
\hline $\mathrm{GA}_{3}+\mathrm{CPPU}$ & $15.0 \pm 0.1 \mathrm{a}$ & $16.0 \pm 1.1 \mathrm{a}$ & $380.1 \pm 11.5 \mathrm{a}$ & $393.0 \pm 1.2 \mathrm{a}$ & $19.0 \pm 0.6 \mathrm{a}$ & $19.9 \pm 0.3 \mathrm{a}$ & $290 \pm 5.7 \mathrm{a}$ & $320 \pm 2.8 \mathrm{a}$ & $14.4 \pm 0.3 b$ & $14.1 \pm 0.2 \mathrm{~b}$ \\
\hline
\end{tabular}

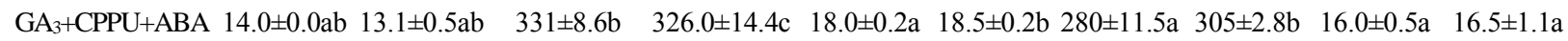

Control (water); $\mathrm{GA}_{3}$, gibberellic acid; CPPU, forchlorfenuron; ABA, abscisic acid. Means in a column followed by a different letter differ significantly at $\mathrm{P}=0.05$ by Duncan test

${ }^{a}$ means of three replicates (each replicate $=2$ vines $) \pm \mathrm{SE}$

Table 2. Effect of the growth regulators on berry TSS, TA, firmness, and initial harvest of 'Flame Seedless' grape at harvest during 2016 and 2017 seasons

\begin{tabular}{lcccccccc}
\hline \multirow{2}{*}{ Treatments } & \multicolumn{2}{c}{$\begin{array}{c}\text { TSS } \\
(\%)\end{array}$} & \multicolumn{2}{c}{$\begin{array}{c}\text { TA } \\
(\%)\end{array}$} & & \multicolumn{2}{c}{$\begin{array}{c}\text { Firmness } \\
(\mathrm{N})\end{array}$} & \multicolumn{2}{c}{$\begin{array}{c}\text { Initial harvest days } \\
\text { comparing with the } \\
\text { control (days) }\end{array}$} \\
\cline { 2 - 10 } & 2016 & 2017 & 2016 & 2017 & 2016 & 2017 & 2016 & 2017 \\
\hline Control & $19.7 \pm 0.11^{\mathrm{a} a}$ & $19.2 \pm 0.17 \mathrm{a}$ & $0.69 \pm 0.01 \mathrm{~b}$ & $0.70 \pm 0.01 \mathrm{a}$ & $3.9 \pm 0.11 \mathrm{c}$ & $3.2 \pm 0.30 \mathrm{~b}$ & zero & zero \\
\hline $\mathrm{GA}_{3}$ & $18.6 \pm 0.18 \mathrm{~b}$ & $17.5 \pm 0.17 \mathrm{~b}$ & $0.71 \pm 0.00 \mathrm{~b}$ & $0.71 \pm 0.01 \mathrm{a}$ & $4.5 \pm 0.28 \mathrm{~b}$ & $4.3 \pm 0.37 \mathrm{a}$ & $+8 \pm 0.01$ & $+7 \pm 0.01$ \\
\hline $\mathrm{CPPU}$ & $18.1 \pm 0.23 \mathrm{~b}$ & $17.1 \pm 0.23 \mathrm{~b}$ & $0.70 \pm 0.01 \mathrm{~b}$ & $0.70 \pm 0.01 \mathrm{a}$ & $5.2 \pm 0.25 \mathrm{a}$ & $4.5 \pm 0.28 \mathrm{a}$ & $+10 \pm 0.01$ & $+9 \pm 0.01$ \\
\hline $\mathrm{GA}_{3}+\mathrm{CPPU}$ & $18.2 \pm 0.17 \mathrm{~b}$ & $17.7 \pm 0.17 \mathrm{~b}$ & $0.74 \pm 0.01 \mathrm{a}$ & $0.72 \pm 0.01 \mathrm{a}$ & $4.9 \pm 0.08 \mathrm{ab}$ & $4.3 \pm 0.18 \mathrm{a}$ & $+11 \pm 0.01$ & $+10 \pm 0.01$ \\
\hline $\mathrm{GA}_{3}+\mathrm{CPPU}+\mathrm{ABA}$ & $20.1 \pm 0.57 \mathrm{a}$ & $19.0 \pm 0.31 \mathrm{a}$ & $0.69 \pm 0.01 \mathrm{~b}$ & $0.70 \pm 0.01 \mathrm{a}$ & $3.8 \pm 0.11 \mathrm{c}$ & $3.2 \pm 0.47 \mathrm{~b}$ & $-3 \pm 0.01$ & $-5 \pm 0.01$ \\
\hline
\end{tabular}

Note: See Table 1 
Table 3. Effect of the growth regulators on lightness $\left(\mathrm{L}^{*}\right)$, chroma $\left(\mathrm{C}^{*}\right)$, hue $\left(\mathrm{h}^{\circ}\right)$, and anthocyanin content of 'Flame Seedless' grape skin at harvest during 2016 and 2017 seasons

\begin{tabular}{|c|c|c|c|c|c|c|c|c|}
\hline \multirow[t]{2}{*}{ Treatments } & \multicolumn{2}{|c|}{$L$} & \multicolumn{2}{|c|}{ C } & \multicolumn{2}{|c|}{$h^{\circ}$} & \multicolumn{2}{|c|}{$\begin{array}{c}\text { Anthocyanin } \\
\text { (mg per } 100 \mathrm{~g} \text { fresh } \\
\text { weight) }\end{array}$} \\
\hline & 2016 & 2017 & 2016 & 2017 & 2016 & 2017 & 2016 & 2017 \\
\hline Control & $33.2 \pm 0.57 \mathrm{c}$ & $34.3 \pm 0.57 \mathrm{~b}$ & $15.1 \pm 0.72 \mathrm{a}$ & $13.2 \pm 0.69 \mathrm{~b}$ & $76.2 \pm 0.86 \mathrm{c}$ & $75.5 \pm 0.40 \mathrm{c}$ & $4.8 \pm 0.46 \mathrm{a}$ & $5.1 \pm 0.50 \mathrm{~b}$ \\
\hline $\mathrm{GA}_{3}$ & $38.3 \pm 0.37 \mathrm{~b}$ & $39.1 \pm 0.37 \mathrm{a}$ & $16.1 \pm 0.43 \mathrm{a}$ & $16.2 \pm 0.38 \mathrm{a}$ & $90.1 \pm 0.72 \mathrm{a}$ & $89.1 \pm 0.25 \mathrm{a}$ & $2.3 \pm 0.14 \mathrm{~b}$ & $3.9 \pm 0.05 \mathrm{c}$ \\
\hline CPPU & $39.1 \pm 0.54 \mathrm{~b}$ & $39.2 \pm 0.54 \mathrm{a}$ & $16.3 \pm 0.51 \mathrm{a}$ & $15.6 \pm 0.89 \mathrm{a}$ & $89.5 \pm 0.51 \mathrm{a}$ & $81.2 \pm 0.64 \mathrm{~b}$ & $2.0 \pm 0.27 \mathrm{~b}$ & $2.3 \pm 0.66 \mathrm{~d}$ \\
\hline $\mathrm{GA}_{3}+\mathrm{CPPU}$ & $40.9 \pm 0.26 \mathrm{a}$ & $39.6 \pm 0.26 \mathrm{a}$ & $16.9 \pm 0.38 \mathrm{a}$ & $16.0 \pm 0.50 \mathrm{a}$ & $86.1 \pm 0.28 \mathrm{~b}$ & $90.1 \pm 0.40 \mathrm{a}$ & $2.3 \pm 0.86 \mathrm{~b}$ & $3.5 \pm 0.12 \mathrm{c}$ \\
\hline $\mathrm{GA}_{3}+\mathrm{CPPU}+\mathrm{ABA}$ & $31.2 \pm 0.37 \mathrm{~d}$ & $32.1 \pm 0.37 \mathrm{c}$ & $13.2 \pm 0.49 b$ & $11.9 \pm 0.34 \mathrm{a}$ & $40.2 \pm 0.69 \mathrm{~d}$ & $38.2 \pm 0.44 \mathrm{~d}$ & $6.5 \pm 1.15 \mathrm{a}$ & $8.7 \pm 0.17 \mathrm{a}$ \\
\hline
\end{tabular}

Note: See Table 1

Table 4. Effect of the growth regulators on berries firmness $(\mathrm{N})$, weight loss $(\%)$, shattering (\%), and unmarketable berries (\%) of 'Flame Seedless' grape after 7 days at $20{ }^{\circ} \mathrm{C}(\mathrm{RH}=80-85 \%)$ during 2016 and 2017 seasons

\begin{tabular}{lcccccccc}
\hline \multirow{2}{*}{ Treatments } & \multicolumn{2}{c}{ Firmness (N) } & \multicolumn{2}{c}{ Weight loss $(\%)$} & \multicolumn{2}{c}{ Shattering $(\%)$} & \multicolumn{2}{c}{ Unmarketable berries (\%) } \\
\cline { 2 - 9 } & 2016 & 2017 & 2016 & 2017 & 2016 & 2017 & 2016 & 2017 \\
\hline Control & $3.0 \pm 0.57 \mathrm{a} a$ & $3.0 \pm 0.05 \mathrm{~b}$ & $6.5 \pm 0.28 \mathrm{a}$ & $7.4 \pm 0.23 \mathrm{a}$ & $25.3 \pm 0.49 \mathrm{a}$ & $29.5 \pm 0.86 \mathrm{a}$ & $7.5 \pm 0.28 \mathrm{a}$ & $9.6 \pm 0.51 \mathrm{a}$ \\
\hline $\mathrm{GA}_{3}$ & $4.0 \pm 0.57 \mathrm{a}$ & $4.0 \pm 0.02 \mathrm{a}$ & $4.5 \pm 0.28 \mathrm{bc}$ & $4.9 \pm 0.23 \mathrm{~b}$ & $10.2 \pm 0.11 \mathrm{c}$ & $12.3 \pm 0.40 \mathrm{c}$ & $2.9 \pm 0.34 \mathrm{c}$ & $3.0 \pm 0.57 \mathrm{~b}$ \\
\hline $\mathrm{CPPU}$ & $4.1 \pm 0.57 \mathrm{a}$ & $4.1 \pm 0.54 \mathrm{a}$ & $5.3 \pm 0.17 \mathrm{~b}$ & $5.1 \pm 0.23 \mathrm{~b}$ & $10.5 \pm 0.57 \mathrm{c}$ & $11.8 \pm 0.46 \mathrm{c}$ & $3.6 \pm 0.51 \mathrm{bc}$ & $3.5 \pm 0.28 \mathrm{~b}$ \\
\hline $\mathrm{GA}_{3}+\mathrm{CPPU}$ & $4.2 \pm 0.40 \mathrm{a}$ & $3.9 \pm 0.06 \mathrm{a}$ & $3.2 \pm 0.46 \mathrm{~d}$ & $3.7 \pm 0.17 \mathrm{c}$ & $9.5 \pm 0.28 \mathrm{c}$ & $10.5 \pm 0.86 \mathrm{c}$ & $2.5 \pm 0.28 \mathrm{c}$ & $3.2 \pm 0.0 \mathrm{~b}$ \\
\hline $\mathrm{GA}_{3}+\mathrm{CPPU}+\mathrm{ABA}$ & $3.0 \pm 0.57 \mathrm{a}$ & $2.8 \pm 0.11 \mathrm{~b}$ & $4.3 \pm 0.17 \mathrm{c}$ & $5.3 \pm 0.40 \mathrm{~b}$ & $15.5 \pm 0.28 \mathrm{~b}$ & $18.1 \pm 1.12 \mathrm{~b}$ & $4.6 \pm 0.23 \mathrm{~b}$ & $4.1 \pm 0.11 \mathrm{~b}$ \\
\hline
\end{tabular}

Note: See Table 1

In terms of colorimetric parameter in both seasons, the data in Table 3 show that berries sprayed with $\mathrm{GA}_{3}, \mathrm{CPPU}$, and $\mathrm{GA}_{3}+\mathrm{CPPU}$ had significantly higher lightness $\left(L^{*}\right)$, saturation $\left(C^{*}\right)$, and hue $\left(h^{\circ}\right)$ values compared to the control and $\mathrm{GA}_{3}+$ $\mathrm{CPPU}+\mathrm{ABA}$. Among $\mathrm{GA}_{3}, \mathrm{CPPU}$, and $\mathrm{GA}_{3}+$ CPPU treatments, there was no significant differences except $\mathrm{GA}_{3}+\mathrm{CPPU}$ treatment with $L^{*}$ and $h^{\circ}$ in the first season and CPPU treatment with $h^{\circ}$ in the second season. $\mathrm{GA}_{3}+\mathrm{CPPU}+\mathrm{ABA}$ treatment had significantly the lowest lightness $\left(L^{*}\right)$, saturation $\left(C^{*}\right)$, and hue $\left(h^{\circ}\right)$ values compared to the other treatments and control. A significant decrease in anthocyanin content was recorded in the result of spraying with $\mathrm{GA}_{3}, \mathrm{CPPU}$, and $\mathrm{GA}_{3}+\mathrm{CPPU}$ compared to the control treatment and $\mathrm{GA}_{3}+\mathrm{CPPU}+$ ABA in both seasons (Table 3 ).

\section{Shelf life}

In the first season, firmness after the storage was not affected due to application of growth regulators, and in the second season, spraying with $\mathrm{GA}_{3}, \mathrm{CPPU}$, $\mathrm{GA}_{3}+\mathrm{CPPU}$ kept firmness of berries above the control and $\mathrm{GA}_{3}+\mathrm{CPPU}+\mathrm{ABA}$ treatment. All applied growth regulators reduced weight loss, berry shattering, and decreased unmarketable berries' percentages as compared to the control (Table 4).

\section{DISCUSSION}

Coinciding increase in the yield of the grapevines by different $\mathrm{GA}_{3}$ and CPPU treatments was reported earlier (Zoffoli et al. 2009; Al-Obeed 2011; Dimovska et al. 2011; Abu-Zahra \& Salameh 2012). Strydom (2013) showed an increase in the yield of grapevines 'Flame Seedless', 'Redglobe', and 'Crimson Seedless' by spraying with CPPU. The role of pre-harvest application of $\mathrm{GA}_{3}+\mathrm{CPPU}$ in increasing fruit yield was previously stated in mango and grapes (Notodimedjo 2000; Han \& Lee 2004).

Plant growth regulators, especially $\mathrm{GA}_{3}$ and CPPU are frequently applied at low concentrations to seedless table grape cultivars in order to increase berry and cluster weight (Zabadal \& Bukovac 2006; 
Han \& Lee 2004; Retamales et al. 1995; Notodimedjo 2000; Lee \& Han 2001; Du Plessis 2008; Zoffoli et al. 2009; Gholami et al. 2010). Grapevines are commonly treated from flowering to fruit stage with $\mathrm{GA}_{3}$ and CPPU to extend the flowering period and increase cluster weight and length ( $\mathrm{Li}$ et al. 2015). The effect of $\mathrm{GA}_{3}$ on stimulating cell division and cell expansion, and on increasing fruits size was previously reported (Liu et al. 2006; Valero 2010; Raath 2012). $\mathrm{GA}_{3}$ is also reported to stimulate growth by promoting plasticity of the cell walls and the hydrolysis of starch into sugars that reduces the cells' water potential, inducing the entry of water into the cells and causing elongation and expansion (Marini 2006). CPPU has been revealed to induce both division and elongation of cells, which increases berry size when applied after fruit set to berries (Dokoozlian 2000). The combined treatment of $\mathrm{GA}_{3}$ and CPPU increased the clusters and berries' weight more than $\mathrm{GA}_{3}$ or CPPU alone, suggesting the synergistic effect between cytokinin and gibberellin. This result goes in line with those of Zoffoli et al. (2009), Ferrara et al. (2014), and Xu et al. (2019).

In this study, decrease in berry firmness was evident in grapes subjected to $\mathrm{GA}_{3}+\mathrm{CPPU}+\mathrm{ABA}$ treatment in both seasons. ABA application may negatively affect berries' firmness, a critical characteristic for the profitable postharvest handling of grapes for the fresh market because it affects shelf life and transportability (Batista et al. 2015). ABA application is well known to cause decrease and loosening rigidity of the cell wall, leading to fruit softening and berries' cracking (Thomas et al. 2008; Gambetta et al. 2010). Treatment of grapes with ABA can result in the induction of cell wall degrading genes, as polygalacturonases that promote pectin depolymerization and solubilization (Koyama et al. 2010). Such an effect of ABA on grape firmness was also recorded in 'Flame Seedless', (Peppi et al. 2006) in 'Red Globe' (Peppi et al. 2007), and 'Crimson Seedless' (Lurie et al. 2010) grapes, where it induced softening similar to that caused by ethephon applications.

Our results concerning berry firmness are consistent with the results from the previous work on other cultivars. Ben-Arie et al. (1998) found that $\mathrm{GA}_{3}$ in combination with CPPU increased berry firmness of 'Superior Seedless' grape. Melillo (2005) and Avenant and Avenant (2006) found that 'Redglobe' berry firmness increased when CPPU was applied at veraison stage, and Peppi and Fidelibus (2008) reported a linear increase in 'Flame Seedless' berry firmness with CPPU at various concentrations. The increase in berries firmness by $\mathrm{GA}_{3}$ and CPPU application could be attributed to their influence on delaying or reducing different phases of ripening (softening). Moreover, application of $\mathrm{GA}_{3}$ and CPPU leads to delay senescence (Abeles et al. 1992). Besides, the lowest TSS, increased firmness, and delay of color development may be a result of the role of $\mathrm{GA}_{3}$ and CPPU in delaying berry maturation (Zabadal \& Bukovac 2006). $\mathrm{GA}_{3}$ application should determine a reduction of sugar accumulation because of the occurrence of larger berry size (Crupi et al. 2016). On the contrary, girdling either alone or in combination with $\mathrm{GA}_{3}$ caused an increment of TSS in mature grapes as found by Abu-Zahra and Salameh (2012).

Fruit color is an important factor in determining fruit marketability, along with total soluble solids (TSS) and titratable acidity (TA). Lowered TSS content, increased TA (Zoffoli et al. 2009) and lowered anthocyanin concentration (Peppi \& Fidelibus 2008) due to $\mathrm{GA}_{3}$ and CPPU were confirmed in this study. Increased TA is related to a delay in harvest date. The reduction of sugar accumulation as a result of $\mathrm{GA}_{3}$ application may be connected with the higher berry size (Crupi et al. 2016). However, according to the maturity indices of the UNECE (2011), a minimum value of $16^{\circ} \mathrm{Brix}$ is required for 'Flame Seedless' and, in this study, $\mathrm{GA}_{3}$ and CPPU resulted in a TSS of $18^{\circ}$ Brix and higher. $\mathrm{GA}_{3}$ and CPPU delay fruit maturity because of lower TSS, $\mathrm{pH}$ and slower color accumulation (Ben-Arie et al. 1998 and Du Plessis 2008). For example, $3 \mathrm{mg} \cdot \mathrm{dm}^{-3} \mathrm{CPPU}$, applied to 'Crimson Seedless' at 6 to $10 \mathrm{~mm}$ berry diameter, resulted in increased TA but lower anthocyanin concentrations (Strydom 2013). In this study, exogenous application of ABA enhances the color of grapes by improving the anthocyanin synthesis and accumulation in the berries' skin (Cantín et al. 2007 and Koyama et al. 2018). Consistent with the results obtained for 'Flame Seedless' grapes, anthocyanin concentrations increased with the application of $300 \mathrm{mg} \cdot \mathrm{dm}^{-3}$ ABA during veraison stage (Peppi et al. 2006). 
In addition, Koyama et al. (2018) reported that application of ABA $400 \mathrm{mg} \cdot \mathrm{dm}^{-3}$ resulted in a higher accumulation of the individual anthocyanins and total anthocyanins. Moreover, in our experiment, anthocyanin content was considerably increased by $\mathrm{GA}_{3}+\mathrm{CPPU}+\mathrm{ABA}$ treatment. Han and Lee (2004) reported that $\mathrm{ABA}$ added to $\mathrm{GA}_{3}$ and $\mathrm{CPPU}$ increased anthocyanin content more than two-fold as compared to the control. The decrease of anthocyanin content by $\mathrm{GA}_{3}$ and/or CPPU could be the result of their effect on phenylalanine ammonia-lyase (PAL) activity, which is considered as the key enzyme in the synthesis of anthocyanin (Lee et al. 1996). ABA plays an important role in stimulating the enzyme. In this study, the initial harvest date is generally delayed approximately by 10 days by $\mathrm{GA}_{3}$, CPPU, and $\mathrm{GA}_{3}+\mathrm{CPPU}$ treatments. However, a sufficient color and TSS contents were developed (Retamales et al. 1995; Du Plessis 2008). Exogenous ABA application has the potential to decrease the time to harvest, which is advantageous for the marketing of grapes (Cantín et al. 2007; Ferrara et al. 2015).

The increase in the keeping quality of the berries during the shelf life obtained in the current study might be interpreted by the positive influence of the $\mathrm{GA}_{3}$ and CPPU in increasing fruit firmness, reducing weight loss, and delaying ripening (El-Otmani \& Coggins 1991; Ben-Arie et al. 1998; Tumminelli et al. 2005; Samara et al. 2007). The delay may also be the main reason for the greater firmness and decrease in the shattering percentage of the berries. Moreover, this result could be attributed to the alterations in cluster and berries' anatomy. According to Ben-Arie et al. (1998), the increase in the rachis weight was a result of an increased thickness of the pedicels, subsequently reinforcing the attachment of the berries and lessening the percentage of shattering.

\section{CONCLUSION}

The combined use of $\mathrm{GA}_{3}$ at $25 \mathrm{mg} \cdot \mathrm{dm}^{-3}$ and CPPU at $10 \mathrm{mg} \cdot \mathrm{dm}^{-3}$ was effective to improve the berry size and fruit quality of 'Flame Seedless' grape, although they had a negative impact on coloration. This problem may be overcome by using the application of exogenous $\mathrm{ABA}$ at $300 \mathrm{mg} \cdot \mathrm{dm}^{-3}$ at $\mathrm{BBCH}-$ 81 phase. Moreover, pre-harvest application of $\mathrm{GA}_{3}$ and CPPU at the early stages of fruit enlargement had a positive influence on increasing the yield and improving the berry and cluster physical characteristics, as well as extending the shelf life.

\section{Acknowledgments}

The author would like to thank Project: Collective action and agricultural productivity in Egypt's new lands (Nasr canal area); STDF-IRD Joint Innovation Projects: Fund No. 4652, for providing chemicals and instruments for this research. (Project Egyptian PI: Dr. Diaa O. El-Ansary, Precision Agricultural Laboratory, Department of Pomology, Faculty of Agriculture, ElShatby, University of Alexandria, Alexandria, Egypt).

\section{REFERENCES}

Abeles F.B., Morgan P.W., Saltveit M.E. Jr. 1992. Ethylene in Plant Biology, 2nd ed. Academic Press, USA, 414 p. DOI: 10.1016/c2009-0-03226-7.

Abu-Zahra T.R., Salameh N.M. 2012. Influence of gibberellic acid and cane girdling on berry size of Black Magic grape cultivar. Middle-East Journal of Scientific Research 11(6): 718-722.

Adi Reddy P., Manohar Prasad D. 2012. Effect of plant growth regulators on fruit characters and yield of pomegranate (Punica granatum L.) cv. Ganesh. International Journal of Plant, Animal and Environmental Sciences 2: 91-93.

Al-Obeed R.S. 2011. Enhancing the shelf life and storage ability of Flame seedless grapevine by agrochemicals preharvest foliar applications. Middle-East Journal of Scientific Research 8: 319-327.

AOAC 1995. Official Methods of Analysis, 16th ed. Association of Official Analytical Chemists, USA.

Avenant J.H., Avenant E. 2006. The effect of ethephon on berry color of 'Crimson Seedless' and 'Ebony Star' table grapes. Acta Horticulturae 727: 381-388. DOI: 10.17660/actahortic.2006.727.45.

Batista P.F., de Lima M.A.C., de Souza Leão P.C., de França Souza F., Alves R.E. 2015. Genetic divergence among grapevine varieties from the Active Germplasm Bank of Embrapa Semiárido. Revista Ciência Agronômica 46: 800-808. DOI: 10.5935/1806-6690.20150068. [in Portuguese with English abstract]

Ben-Arie R., Sarig P., Cohen-Ahdut Y., Zutkhi Y., Sonego L., Kapulonov T., Lisker N. 1998. CPPU and $\mathrm{GA}_{3}$ effects on pre- and post-harvest quality of seedless and seeded grapes. Acta Horticulturae 463: 349-358. DOI: $10.17660 /$ actahortic.1998.463.44. 
Cantín C.M., Fidelibus M.W., Crisosto C.H. 2007. Application of abscisic acid (ABA) at veraison advanced red color development and maintained postharvest quality of 'Crimson Seedless' grapes. Postharvest Biology and Technology 46: 237-241. DOI: 10.1016/j.postharvbio.2007.05.017.

Casanova L., Casanova R., Moret A., Agustí M. 2009. The application of gibberellic acid increases berry size of 'Emperatriz' seedless grape. Spanish Journal of Agricultural Research 7: 919-927. DOI: 10.5424/sjar/2009074-1105.

Crupi P., Antonacci D., Savino M., Genghi R., Perniola R., Coletta A. 2016. Girdling and gibberellic acid effects on yield and quality of a seedless red table grape for saving irrigation water supply. European Journal of Agronomy 80: 21-31. DOI: 10.1016/j.eja.2016.06.015.

Dimovska V., Ivanova V., Ilieva F., Sofijanova E. 2011. Influence of bioregulator gibberellic acid on some technological characteristics of cluster and berry from some seedless grape varieties. Journal of Agricultural Science and Technology 1: 1054-1058.

Dokoozlian N.K. 2000. Plant growth regulator use for table grape production in California. Proceedings of the 4th International Symposium on Table Grape. Instituto de Investigaciones Agropecuarias, Chile, pp. 129-143.

Duarte A.M.M., García-Luis A., Molina R.V., Monerri C., Navarro V., Nebauer S.G. et al. 2006. Long-term effect of winter gibberellic acid sprays and auxin application on crop value of 'Clausellina' satsuma. Journal of the American Society for Horticultural Science 131: 586-592. DOI: 10.21273/jashs.131.5.586.

du Plessis B.W. 2008. Cellular factors that affect table grape berry firmness. MS Thesis, Stellenbosch University, South Africa, $85 \mathrm{p}$.

El Gammal O.H.M., Salama A.S.M., Bakeer S.M.M. 2015. Effect of growth regulator, antioxidant and application date on fruiting and fruit quality of mango trees cv. Keitt. IOSR Journal of Agriculture and Veterinary Science 8: 87-95. DOI: 10.9790/2380-081218795.

El-Otmani M., Coggins C.W. Jr. 1991. Growth regulator effects on retention of quality of stored citrus fruits. Scientia Horticulturae 45: 261-272. DOI: 10.1016/0304-4238(91)90072-7.

Ferrara G., Mazzeo A., Netti G., Pacucci C., Matarrese A.M.S., Cafagna I. et al. 2014. Girdling, gibberellic acid, and forchlorfenuron: Effects on yield, quality, and metabolic profile of table grape cv. Italia.
American Journal of Enology and Viticulture 65: 381-387. DOI: 10.5344/ajev.2014.13139.

Ferrara G., Mazzeo A., Matarrese A.M.S., Pacucci C., Punzi R., Faccia M. et al. 2015. Application of abscisic acid (S-ABA) and sucrose to improve colour, anthocyanin content and antioxidant activity of $\mathrm{cv}$. Crimson Seedless grape berries. Australian Journal of Grape and Wine Research 21: 18-29. DOI: 10.1111/ajgw.12112.

Gény L., Deytieux C., Donèche B. 2005. Importance of hormonal profile on the onset of ripening in grape berries of Vitis vinifera L. Acta Horticulturae 682: 99-105. DOI: 10.17660/actahortic.2005.682.6.

Gambetta G.A., Matthews M.A., Shaghasi T.H., McElrone A.J., Castellarin S.D. 2010. Sugar and abscisic acid signaling orthologs are activated at the onset of ripening in grape. Planta 232: 219-234. DOI: 10.1007/s00425-010-1165-2.

Gholami M., Sedighi A., Ershadi A., Sarikhani H. 2010. Effect of pre- and postharvest treatments of salicylic and gibberellic acid on ripening and some physicochemical properties of 'Mashhad' sweet cherry (Prunus avium L.) fruit. Acta Horticulturae 884: 257-264. DOI: 10.17660/actahortic.2010.884.30.

Han D.H., Lee C.H. 2004. The effects of $\mathrm{GA}_{3}$, CPPU and ABA applications on the quality of Kyoho (Vitis vinifera L. $\times$ V. labrusca L.) grape. Acta Horticulturae 653: 193-197. DOI: 10.17660/actahortic.2004.653.27.

He F., Mu L., Yan G.-L., Liang N.-N., Pan Q.-H., Wang J. et al. 2010. Biosynthesis of anthocyanins and their regulation in colored grapes. Molecules 15: 9057-9091. DOI: 10.3390/molecules15129057.

Khandaker M.M., Osman N., Hossain A.S., Faruq G., Boyce A.N. 2015. Effect of 2,4-D on growth, yield and quality of wax apple (Syzygium samarangense, [Blume] Merrill \& L.M. Perry var. Jambu Madu) fruits. Sains Malaysiana 44: 1431-1439. DOI: 10.17576/jsm-2015-4410-08.

Korkutal I., Bahar E., Gökhan Ö. 2008. The characteristics of substances regulating growth and development of plants and the utilization of gibberellic acid $\left(\mathrm{GA}_{3}\right)$ in viticulture. World Journal of Agricultural Sciences 4: 321-325.

Koyama K., Sadamatsu K., Goto-Yamamoto N. 2010. Abscisic acid stimulated ripening and gene expression in berry skins of the Cabernet Sauvignon grape. Functional and Integrative Genomics 10: 367-381. DOI: 10.1007/s10142-009-0145-8. 
Koyama R., Roberto S.R., de Souza R.T., Borges W.F.S., Anderson M., Waterhouse A.L. et al. 2018. Exogenous abscisic acid promotes anthocyanin biosynthesis and increased expression of flavonoid synthesis genes in Vitis vinifera $\times$ Vitis labrusca table grapes in a subtropical region. Frontiers in Plant Science 9; 323, 12 p. DOI: 10.3389/fpls.2018.00323.

Koyama R., Colombo R.C., Borges W.F.S., Silvestre J.P., Hussain I., Shahab M. et al. 2019. Abscisic acid application affects color and acceptance of the new hybrid 'BRS Melodia' seedless grape grown in a subtropical region. HortScience 54: 1055-1060. DOI: 10.21273/hortsci13872-19.

Lee S.M., Han D.H., Lee C.H., Kim S.B. 1996. Effects of $\mathrm{ABA}$ and kinetin treatments on the coloration and quality of 'Campbell Early' and 'Black Olympia' grapes. Journal of the Korean Society for Horticultural Science 37: 263-268.

Lee C., Han D. 2001. The effects of GA3, CPPU and ABA applications on the quality of Kyoho (Vitis vinifera L. $\times$ V. labrusca L.) grape. Acta Horticulturae 653: 193-197. DOI: 10.17660/actahortic.2004.653.27.

Li Y., Kim J.I., Pysh L., Chapple C. 2015. Four isoforms of Arabidopsis 4-coumarate:CoA ligase have overlapping yet distinct roles in phenylpropanoid metabolism. Plant Physiology 169: 2409-2421. DOI 10.1104/pp.15.00838.

Liu J.-H., Honda C., Moriguchi T. 2006. Involvement of polyamine in floral and fruit development. Japan Agricultural Research Quarterly 40: 51-58. DOI: 10.6090/jarq.40.51.

Lurie S., Lichter A., Kaplunov T., Zutahy Y., OrenShamie M., Ovadia R. 2010. Improvement of 'Crimson Seedless' grape colour by abscisic acid treatment. Acta Horticulturae 880: 183-189. DOI: 10.17660/actahortic.2010.880.20.

Marini R.P. 2006. How to grow big peaches. USA, 8 p. https://njaes.rutgers.edu/peach/orchard/pdf/How-toGrow-Big-Peaches.pdf

Melillo M. 2005. Influence of synthetic cytokinins on the growth and composition of several table grapes ( $\mathrm{Vi}$ tis vinifera L.) cultivars. MS Thesis, University of California, USA.

Muchjajib S., Muchjajib U., Jumee M. 2016. Effects of GA and NAA application and fruit wrapping on yield and quality of java apple (Syzygium samarangense (Blum) Merrill \& Perry). Acta Horticulturae 1130: 225-230. DOI: 10.17660/actahortic.2016.1130.33.

Notodimedjo S. 2000. Effect of $\mathrm{GA}_{3}$, NAA and CPPU on fruit retention, yield and quality of mango $(\mathrm{CV}$. Arumanis) in East Java. Acta Horticulturae 509: 587-600. DOI: 10.17660/actahortic.2000.509.67.
Olivares D., Contreras C., Muñoz V., Rivera S., González-Agüero M., Retamales J., Defilippi B.G. 2017. Relationship among color development, anthocyanin and pigment-related gene expression in 'Crimson Seedless' grapes treated with abscisic acid and sucrose. Plant Physiology and Biochemistry 115: 286-297. DOI: 10.1016/j.plaphy.2017.04.007.

Peppi M.C. 2004. Color development studies in table grapes. MS Thesis, University of California, USA, $162 \mathrm{p}$

Peppi M.C., Fidelibus M.W. 2008. Effects of forchlorfenuron and abscisic acid on the quality of 'Flame Seedless' grapes. HortScience 43: 173-176. DOI: 10.21273/hortsci.43.1.173.

Peppi M.C., Fidelibus M.W., Dokoozlian N. 2006. Abscisic acid application timing and concentration affect firmness, pigmentation, and color of 'Flame Seedless' grapes. HortScience 41: 1440-1445. DOI: $10.21273 /$ hortsci.41.6.1440.

Peppi M.C., Fidelibus M.W., Dokoozlian N.K. 2007. Application timing and concentration of abscisic acid affect the quality of 'Redglobe' grapes. Journal of Horticultural Science and Biotechnology 82: 304 310. DOI: 10.1080/14620316.2007.11512233.

Ponce M.T., Guiñazú M., Tizio R. 2002. Effect of putrescine on embryo development in the stenospermocarpic grape cvs Emperatriz and Fantasy. Vitis 41: 53-54. DOI: 10.5073/vitis.2002.41.53-54

Raath P.J. 2012. Effect of varying levels of nitrogen, potassium and calcium nutrition on table grape vine physiology and berry quality. Thesis, Private Bag X1, 7602 Matieland, Stellenbosch University, South Africa.

Retamales J., Bangerth F., Cooper T., Callejas R. 1995. Effects of CPPU and $\mathrm{GA}_{3}$ on fruit quality of Sultanina table grape. Acta Horticulturae 394: 149157. DOI: 10.17660/actahortic.1995.394.14.

Samara N.R., El-Kady M.I., Shalan A.M. 2007. Effect of pre-harvest treatment on improving fruit quality and storage ability of apricots. Mansoura Journal of Agricultural Science 32(9); ID 11831194; pp. 7527-7536.

Snedecor G.W., Cochran W.G. 1989. Statistical Methods, 8th ed. Iowa State University Press, USA, 503 p.

Strydom J. 2013. Effect of CPPU ( $N$-(2-chloro-4-pyridinyl)- $N$ '-phenylurea) and a seaweed extract on Flame Seedless, Redglobe and Crimson Seedless grape quality. South African Journal of Enology and Viticulture 34: 233-240. DOI: 10.21548/34-2-1099.

Szyjewicz E., Rosner N., Kliewer W.M. 1984. Ethephon ((2-chloroethyl)phosphonic acid, Ethrel, CEPA) in viticulture - A review. American Journal of Enology and Viticulture 35: 117-123. 
Thomas T.R., Shackel K.A., Matthews M.A. 2008. Mesocarp cell turgor in Vitis vinifera L. berries throughout development and its relation to firmness, growth, and the onset of ripening. Planta 228: 1067-1076. DOI: 10.1007/s00425-008-0808-z.

Tumminelli R., Conti F., Maltese U., Pedrotti C., Bordonaro E. 2005. Effects of 2,4-D, 2,4-DP, triclopir and $\mathrm{GA}_{3}$ on pre-harvest fruit drop and senescence of 'Tarocco Comune' blood oranges in Sicilian orchards. Acta Horticulturae 682: 801-806. DOI: 10.17660/actahortic.2005.682.104.

UNECE 2011. UNECE standard for Table Grapes. UNECE/Codex Joint International Workshop on Commercial Quality Standards for Fresh Fruit and Vegetables; 1 May 2011, Mexico City, Mexico.

Valero D. 2010. The role of polyamines on fruit ripening and quality during storage: What is new. Acta
Horticulturae 884: 199-205. DOI: 10.17660/actahortic.2010.884.22.

Xu Y., Hou X., Feng J., Khalil-Ur-Rehman M., Tao J. 2019. Transcriptome sequencing analyses reveals mechanisms of eliminated russet by applying $\mathrm{GA}_{3}$ and CPPU on 'Shine Muscat' grape. Scientia Horticulturae 250: 94-103. DOI: 10.1016/j.scienta.2019.02.048.

Zabadal T.J., Bukovac M.J. 2006. Effect of CPPU on fruit development of selected seedless and seeded grape cultivars. HortScience 41: 154-157. DOI: 10.21273/hortsci.35.3.496d.

Zoffoli J.P., Latorre B.A., Naranjo P. 2009. Preharvest applications of growth regulators and their effect on postharvest quality of table grapes during cold storage. Postharvest Biology and Technology 51: 183192. DOI: 10.1016/j.postharvbio.2008.06.013. 